\title{
Hva vet vi (ikke) om elevers opplevelser med friluftsliv i norsk skole - en gjennomgang av empiriske studier 1974-2014
}

\author{
Kristian Abelsen ${ }^{1 \star}$, og Petter Erik Leirhaug ${ }^{2}$ \\ ${ }^{1}$ Norges idrettshøgskole, seksjon for kroppsøving og pedagogikk, Norge; ${ }^{2}$ Høgskulen på \\ Vestlandet, campus Sogndal, Norge
}

\begin{abstract}
Sammendrag
Artikkelen presenterer en kunnskapsoversikt basert på en systematisk gjennomgang av empiriske studier om friluftsliv i norsk skole der elevers opplevelser eller stemmer kommer til uttrykk. En slik oversikt er ikke tidligere sammenfattet, selv om det er over 40 år siden ordet friluftsliv kom inn i fagplanformuleringene med Mønsterplanen av 1974. 1974 ble derfor valgt som utgangspunkt for studiens søkeperiode, selv om det kan hevdes at opplæring og undervisning som omfatter aktivitet, læring og opphold i natur allerede fra tidlig 1900-tall har vært en del av norsk skoles oppdrag og virke. For søkeperioden fram til 2014 avdekkes 24 studier som møter inklusjonskriteriene, hvorav 18 er master- og hovedfagsoppgaver. Resultatet forteller at foreliggende empirisk basert kunnskap om elevers opplevelser med friluftsliv i skolen er begrenset og ikke tillater å trekke syntetiserte slutninger. Med den reservasjonen som hovedkonklusjon drøfter artikkelen hvilken kunnskap de inkluderte studier kan gi om friluftsliv i skolen ut fra elevers perspektiv.
\end{abstract}

Nøkkelord: Friluftsliv $i$ skolen; uteskole; kroppsøving; elevperspektiv; Norge

\begin{abstract}
The article aims to provide a systematic review of empirical studies on students' experiences with school-based 'friluftsliv' (word used to describe a Nordic tradition of outdoor life). Even though 40 years have passed since the word 'friluftsliv' first entered the national curriculum in Norway and became part of the expected student experience, no such reviews of empirical research from schools have been conducted. The authors reviewed literature published between 1974 - the year 'friluftsliv' became a formulated goal in the new curriculum - and 2014. For this period only 24 studies, of which 18 were master's theses, met the inclusion criteria. The result shows that current research-based knowledge about students' experiences with 'friluftsliv' and nature-based outdoor education in schools is extremely limited, and does not allow us to draw synthesized conclusions. With this as a backdrop, the article presents and discusses how the included studies can contribute to the knowledge of school-based 'friluftsliv'.
\end{abstract}

^Korrespondanse: Kristian Abelsen, Norges idrettshøgskole, Postboks 4014 Ullevål Stadion, 0806 Oslo, Noway. E-mail: kristian.abelsen@nih.no

(C)2017 K. Abelsen og P. E. Leirhaug. This is an Open Access article distributed under the terms of the Creative Commons Attribution 4.0 International License (http://creativecommons.org/licenses/by/4.0/), allowing third parties to copy and redistribute the material in any medium or format and to remix, transform, and build upon the material for any purpose, even commercially, provided the original work is properly cited and states its license.

Citation: K. Abelsen og P. E. Leirhaug. "Hva vet vi (ikke) om elevers opplevelser med friluftsliv $i$ norsk skole - en gjennomgang av empiriske studier 1974-2014.” Fournal for Research in Arts and Sports Education, Vol. 1, 2017, pp. 18-31. http://dx.doi. 
Keywords: School-based friluftsliv; outdoor education; student perspective; physical education; Norway

Received: November, 2016; Accepted: April, 2017; Published: September, 2017

Formålet med artikkelen er å gjennomgå og analysere empiriske studier om elevers opplevelser med friluftsliv i skolen, og drøfte hva disse studiene kan fortelle om friluftsliv som del av opplæringen i norsk skole. Friluftsliv som begrep kom inn i fagdelene av norske læreplaner først med Mønsterplanen fra 1974 (M-74; KUF, 1974), men bruk av natur, og å bygge det som kan kalles friluftslivsverdier, har vært betraktet som en del av skolens oppgave gjennom hele 1900-tallet (Augestad, 2003; Haslestad, 2000). Etter en gjennomgang av M-74 og utkast fra arbeidet mot ny Mønsterplan i 1987 (M-87; KUF, 1987) uttalte Mytting (1991) at han ikke var i tvil om at (opplæring i) friluftsliv har kvaliteter som er sentrale i målsetningene for skolen og derfor potensielt et viktig satsingsfelt. Tilsvarende konklusjoner trekker Repp (1993) i sin grundige analyse av M-87, men presiserer samtidig at «fordi friluftslivsbegrepet er såpass lite avklart i planen, så vil likevel bruken av natur kunne bli svært ulik fra klasse til klasse, fra skole til skole» (s. 98). Backman (2011) har i nyere studier fra Sverige, hvor læreplanene ligner de norske (Annerstedt, 2008), demonstrert at vektlegging av friluftsliv vil kunne bidra til opplæringens mål om å utvikle likeverd og demokratiske holdninger.

Både M-74 og M-87 var rammeplaner hvor fagplandelen beskrev innhold som skoler og lærere skulle gjøre valg ut fra. Reformene på 1990-tallet representerte en ny og mer forpliktende læreplanforståelse, hvor friluftsliv med egne målformuleringer ble noe alle elever skulle møte i opplæringen. Dette ble fulgt opp ved innføring av Kunnskapsløftet i 2006 (LK06). Med økt fokus på grunnleggende ferdigheter og målbart læringsbytte, samt reduksjon i antall målformuleringer for friluftsliv, har det blitt hevdet at reformen innebar en svekking av friluftslivets plass i læreplanen (Gurholt, 2005; Leirhaug \& Klepsvik, 2010). Leirhaug og Arnesen (2016) argumenterer for at den tilsynelatende svekkingen skyldes føringer som ble giort gjeldende for alle fag og emner, og konkluderer derfor med at friluftsliv må sies å ha en sterk posisjon i LK06. Gjennom tiårig grunnskole og inntil tre år i videregående opplæring skal elevene ha fått varierte opplevelser i friluftsliv, og opparbeidet seg kompetanse til å kunne gjennomføre og verdsette enkle turer i norsk natur. Under den generelle del av læreplanen heter det at undervisningen bør «nøre hugen til å ferdes utanfor oppstukne veger, til å bruke kropp og sansar til å oppdage nye stader og til å utforske omverda» (Utdanningsdirektoratet, 2015a). Undervisning og opplæring i friluftsliv skal bidra til felles dannelse og identitetsskaping i samfunnet (Utdanningsdirektoratet, 2015a, Utdanningsdirektoratet, 2015b). Stortingsmeldinga Friluftsliv - Natur som kilde til helse og livskvalitet (Meld. St. 18 (2015-2016), 2016) bekrefter at satsing på friluftsliv i skolen skal inngå som et ledd i å møte framtidige utfordringer. Ser vi på kroppsøving som felles fag, legger LK06 opp til et skolefriluftsliv hvor progresjon og elevenes selvstendiggiøring står sentralt. Et av kompetansemålene etter 10. trinn sier at elevene 


\section{K. Abelsen og P. E. Leirhaug}

«skal kunne planlegge og gjennomføre turer til ulike årstider, også med overnatting» (Utdanningsdirektoratet, 2015b). Tilsvarende finner vi i læreplanen for aktivitetslære 2 på idrettsfag dette kompetansemålet: «Elevene skal kunne planlegge, gjennomføre og vurdere tur med overnatting ute i nytt naturmiljø» (Utdanningsdirektoratet, 2006). Gjennom programfag friluftsliv som en valgmulighet $i$ videregående opplæring og innføring av valgfaget natur, miljø og friluftsliv for trinn 8-10 gis det mulighet for et utvidet tilbud til friluftslivsinteresserte elever. Samtidig som disse to nyvinningene indikerer skolepolitisk vilje for mer friluftsliv i skolen, viser Leirhaug og Arnesens (2016) studie at omfanget friluftslivsundervisning i skolehverdagen for de fleste elever ikke samsvarer med opplæringens intensjoner og læreplanens målsetninger. Med Goodlad og hans samarbeidspartneres (Goodlad, Klein og Tye, 1979) læreplannivåer som teoretisk rammeverk sammenligner de friluftslivets posisjon i den formelle lereplan med hvor mye tid som brukes til friluftslivsundervisning i kroppsøvingsfagets operasjonaliserte lareplan. Leirhaug og Arnesen (2016) avslutter sin studie av friluftsliv i kroppsøvingsfaget med understreking av at det er først med kunnskap om det Goodlad, Klein og Tye (1979) kaller den erfarte lcereplan, hva elevene opplever og får ut av undervisningen, vi kan vurdere om undervisningen fungerer og om friluftslivets potensielle bidrag til læringsutbytte realiseres. Denne artikkelen søker å bidra med en empirisk basert kunnskapsoversikt for den erfarte lereplan knyttet til friluftsliv. Utgangspunktet er en systematisk gjennomgang av norske empiriske studier på friluftsliv i skolen fra perioden 1974-2014. Med en åpen inngang har vi ikke gjort noen avgrensning av friluftslivsbegrepet, men overlatt til studiene selv å definere friluftsliv $i$ skolen som sitt undersøkelsesområde. Vi har formulert følgende problemstilling: Hvilken empirisk kunnskap har vi om elevenes opplevelser med og tanker om friluftsliv i skolen? Før presentasjon og diskusjon av våre funn relatert til problemstillingen, vil neste avsnitt gjøre rede for studiens metodiske overveielser og valg.

\section{Datagrunnlag og metode}

Materialet, som vi baserer denne artikkelen på, er samlet i sammenheng med utarbeidelse av en systematisk oversikt over norske empiriske studier på friluftsliv i skolen fra 1974 til 2014. Startår ble valgt fordi friluftsliv med M-74 for første gang kom eksplisitt til uttrykk i fagplanene. Litteratursøk ble gjort i 2015 og vi valgte å inkludere studier publisert ut 2014. Med utgangspunkt i ulike kombinasjoner av søkeord som «friluftsliv», «skole», «uteskole», «undervisning» og «pedagogikk» ble det søkt via bibliotekenes søkesystem Oria, i Cristin og databasene ERIC og Idunn. Det ble også gjort søk i rapportserier utgitt i régi av høgskoler med idretts- og friluftslivsstudier. Videre ble referanselister i identifiserte arbeider gjennomgått på jakt etter ennå ikke registrerte publikasjoner. Etter en første sortering ut fra utgivelsesår, titler og beskrivelser sto vi igjen med 93 titler. Disse ble skaffet til veie og gjennomgått ut fra følgende inkluderingskriterier: Studien skal 
- ha empiri om friluftsliv i grunnskole eller videregående skole (dette betyr at barnehage og høyere utdanning ekskluderes, og at studien skal presentere resultat fra forskning i skolehverdag eller blant lærere og/eller elever)

- inneholde redegjørelse for metodisk tilnærming

- være publisert som forskningsresultat (i form av artikkel, rapport, avhandling eller oppgave på minimum masternivå) i tidsrommet fra 1974 til og med 2014

54 studier møtte kriteriene. 24 av disse hadde empiri med elevperspektiv eller elev- og lærerperspektiv, og det er disse som utgiør datagrunnlaget i denne artikkelen. Kun en (Jordet, 2007) av de inkluderte studiene er publisert etter kriterier som tilfredsstiller universitets- og høgskolesektorens krav til fagfellevurdering. Resterende studier er enten forskningsrapporter - publisert i regi av institusjoner eller forskningskonferanser - eller studentarbeider. Master- og hovedfagsoppgaver teller 18 av de inkluderte studiene. Selv om disse varierer i kvalitet, vil vi slik Borgen og Engelsrud (2015) argumenterer for kroppsøvingsfaget, hevde at «masterstudentene må betraktes som kunnskapsprodusenter for feltet» (s. 66). Oppgavene utgiør en vesentlig del av foreliggende empirisk dokumentert kunnskap om friluftsliv i skolen, samtidig som det må understrekes at dette er materiale produsert i forskerutdanning og at konklusjoner må leses i lys av dette.

Utarbeidelse av en tabelloversikt med hensiktsmessig indeksering (Timmins \& McCabe, 2005) for hele materialet dannet grunnlaget for analyse av de 24 studiene med elevperspektiv. I tillegg til forskningsperspektiv sorterte indekseringen studiene $\mathrm{i}$ henhold til publikasjonsår, skoleslag og årstrinn, metodisk tilnærming og type publikasjon. Vi hentet fram problemstillingene og skrev et resyme av hovedfunn $\mathrm{i}$ hver enkelt studie.

Arbeidet med oversikt og indeksering avdekte en rekke problemstillinger knyttet til friluftsliv i skolen, men ved gjennomgang av studiene med elevperspektiv, hvor målet var å gjøre en tematisk syntetisering (Thomas \& Harden, 2008), ble det klart at det er noen tema som får mer oppmerksomhet i studiene, både fra elevenes og forskernes side. Sammen med betraktninger over materialet som helhet vil vi i de påfølgende delene av artikkelen løfte fram disse temaene og drøfte hvordan de bidrar med kunnskap om vår problemstilling.

Begge artikkelforfatterne er vokst opp med friluftsliv og arbeider med lærerutdanning og friluftsliv, noe som kan ha betydning for tolkning og analyse. I vår analyse av materialet og den videre diskusjonen har vi tatt på alvor Baumeisters (2013) råd om å prøve å opptre som dommer og jury heller enn advokat ved gjennomføring av litteraturreviewer. Vi tilstreber med andre ord å presentere resultatene nøytralt og samtidig synliggjøre våre overveielser.

\section{Ingen empiriske studier før 1993}

Vi har ikke funnet empiriske arbeider fra de første 18 årene av søkeperioden. Repp (1993) er første studie som tilfredsstiller inklusjonskriteriene. Derimot er det godt 


\section{K. Abelsen og P. E. Leirhaug}

med eksempler på mer teoretisk og pedagogisk baserte artikler om hva friluftsliv i skolen kan og bør være. Haugsjå (1975), Kårhus (1975) og Mytting (1991) er eksempler på dette.

Det ble også, i løpet av disse fra forskningens empiriske «stumme år», gjort utviklingsarbeid med friluftsliv i skolen flere steder. Dokumentasjon og spor av dette finnes, men da uten en klar metode for innsamling av empiri. Den erfarte lereplan omtales sjelden, og elevperspektivet berøres stort sett bare indirekte. Skogvang (1993) gjør en kartlegging i ettertid av friluftslivsvaner hos voksne som var med på et friluftslivsopplegg i gymnasregi i 1970-åra, og i vår sammenheng kan vi notere at $25 \%$ uttrykker at undervisningsopplegg i friluftsliv har hatt positiv innvirkning på deres friluftslivsinteresse. En annen konsekvens av manglende studier på 1970- og 80-tallet, er at det ikke foreligger empirisk basert kunnskap om elevers opplevelser med for eksempel friluftsliv valgfag i ungdomsskolen, et valgfag som vi vet var relativt utbredt og kunne være omfattende både i tid og innhold (Aamelfot, 1994).

Men tilbake til vårt første funn, Repp (1993). Vi drister oss til å påstå at studien er materialets mest ambisiøse på friluftslivets vegne. Den tenderer mot det ideologiske, og tyngdepunktet ligger i friluftsliv- og læreplananalyser og diskusjoner om a) hvilke potensiale friluftslivet har for skolen, og b) hva synes å begrense en mer helhetlig og omfattende bruk av friluftsliv i skolen. Repp (1993) finner at friluftsliv har en begrenset plass i de praksisene han observerer, og selv om han har observert undervisningsdynamikk i to skoler får elevenes stemme aldri eksplisitt plass i det empiriske materialet.

\section{Oversikt over inkluderte studier}

24 studier møtte inklusjonskriteriene. 14 fra grunnskolen og 10 fra videregående skole. Studiene i grunnskolen er fra perioden 1993-2007, mens de 10 studiene i videregående skole er alle fra perioden 2008-2014. Bare tre studier er publisert før 2002. De resterende 21 fordeler seg relativt jevnt fra 2002 til 2014. Dette kan være et uttrykk for en generell interessedreining både politisk og pedagogisk i retning den erfarte lereplan, fra undervisning og innhold til hva elever lærer og opplever. For friluftsliv kan interessen i studier med elevperspektiv i tillegg synes å ha flyttet seg fra grunnskole til videregående skole, en dreining som kan ha sammenheng med innføringen av LK06 i 2006. Skolereformen medførte nye læreplaner for hele opplæringsløpet. Motivene var flere: bedre elevenes evne og lyst til å lære, styrke de grunnleggende ferdighetene og gjøre grunnopplæringen bedre i stand til å møte kunnskapssamfunnets utfordringer (St.meld. nr. 30 (2003-2004), 2004). Det kan hevdes at friluftsliv som tverrfaglig emne og naturen som læringsarena fikk dårligere betingelser etter denne reformen - i hvert fall i de første årene av grunnskolen. I «Har skulen snudd ryggen til naturen?» problematiserer Leirhaug og Klepsvik (2010) dette ut fra økt fokus på fag, regning, lesing og skriving i grunnopplæringa, noe som igjen koples til resultater blant annet i PISA-undersøkelsene.

En annen observasjon når vi ser på studiene fra grunnskolen, er at sju av 14 studier er relatert til uteskole (Abelsen, 2002; Fjørtoft \& Larsen, 2005; Garborg, 2003; 
Grønningseter, Hallås \& Kristiansen, 2005; Jordet, 2007; Jørgensen, 1999; Rødby, 2006). Jordet (2010) definerer uteskole som en «måte å arbeide med skolens innhold på hvor elever og lærere bruker nærmiljø og lokalsamfunn som ressurs i opplæringen for å supplere og utfylle klasseromsundervisningen» (s. 34). En slik definisjon som inkluderer alle former for læringsprosjekter utenfor klasserommet har bred oppslutning, og forteller at uteskole ikke er ensbetydende med friluftsliv i skolen. De inkluderte uteskolestudiene beskriver alle en praksis hvor skolen nytter lokale naturomgivelser og friluftsliv kan sies å ha en sentral plass. Det betyr at materialet ut over uteskolestudiene består av kun sju studier (Eriksen, 1997; Jacobsen mfl., 2002; Jacobsen mfl., 2006; Jakobsen, 2007; Kongsrud, 2004; Repp, 1993; Sølvik, 2003), hvorav to er basert på samme empiri, som fanger opp elevperspektiver mer direkte knyttet til målformuleringer for friluftsliv i grunnopplæringa.

Analysen og oversikten over studiene fører oss til å spørre om det er idrettsfaget som på høyere trinn bidrar til å opprettholde vitaliteten og legitimiteten til friluftsliv i opplæringa? Friluftsliv har siden opprettelse av idrettslinjer hatt en sentral plass i faget aktivitetslære. I tillegg ble det i 2006 åpnet for å opprette programfag friluftsliv ${ }^{1}$. Arbeid med friluftsliv har i disse fagene helt andre betingelser og tidsrammer enn hva lærere uttrykker at skolehverdagen ellers tillater (Jacobsen mfl., 2007; Leirhaug \& Arnesen, 2016). Av de 10 studiene fra videregående opplæring er fire gjennomført på idrettsfag (Bamle, 2009; Gøtz, 2014; Naustdal, 2012; Åvangen, 2008) og fire på programfag friluftsliv (Foss, 2011; Hvattum, 2012; Nygård, 2012; Valdal, 2013). Dermed er det kun to studier fra videregående skole som tar for seg friluftsliv i kroppsøvingsfaget (Mikkelsen, 2013; Wiken, 2011). Vi skal i det følgende se nærmere på empirien i de inkluderte studiene, hvilke sider ved friluftsliv i skolen de tematiserer og hva de kan fortelle om elevers opplevelser.

\section{Metode og forskningsspørsmål i studiene}

Inkluderte studier er i all hovedsak kvalitative. Kun tre studier er basert på kvantitative data, og to av disse faller litt på siden av vår problemstilling ved at de undersøker elevenes aktivitetsnivå ved uteundervisning og uteskole (Fjørtoft \& Larsen, 2005; Grønningseter, Hallås \& Kristiansen, 2005). Begge studiene er småskala og har et lite utvalg, men påviser at elevene ofte kommer opp i en intensitet som bidrar til helsefremmende effekter. Grønningseter, Hallås og Kristiansen (2005) sammenlignet inne- og uteundervisning og fant at intensitetsverdiene på dager med lavest intensitet $\mathrm{i}$ uteskolen fortsatt var høyere enn de høyeste verdiene på en tradisjonell dag inne på skolen.

Tredje studie med kvantitativ tilnærming er Wiken (2011), som har spurt 229 elever fra tre videregående skoler om erfaringer med friluftsliv i kroppsøvingsfaget. 30-40 \% oppgir i liten grad å kjenne fagets kompetansemål. Det er i friluftsliv, orientering og dans de oppgir å ha lært minst. Nesten halvparten rapporterer en

\footnotetext{
${ }^{1}$ Programfag friluftsliv er et valgfritt 5 timers fag for elever på Vg1 og Vg2, åpent for alle elever men plassert under utdanningsprogram for idrettsfag.
} 


\section{K. Abelsen og P. E. Leirhaug}

holdning som tilsier at det er unødvendig å lære om friluftsliv. Elevrapporteringene i studien støttes av andre masterstudier (Dalebø, 1996; Lund, 2014) som peker på at lærere har store utfordringer med å tilrettelegge for et friluftsliv i tråd med læreplanens intensjoner og forventninger.

De tre studiene med kvantitativ tilnærming viser at hva det forskes på og hvilke spørsmål som stilles, berører mer grunnleggende spørsmål om hva friluftsliv i skolen er, hva det kan være og hva det skal bidra med. Kartlegging av aktivitetsnivå knytter bruken av friluftsliv og natur til et folkehelseperspektiv. Det er i tråd med målsettinger i stortingsmeldinga om friluftsliv (Meld. St. 18 (2015-2016), 2016), men inviterer til å diskutere mening fra et friluftsfaglig ståsted; er det aktivitetsnivået i friluftslivsundervisningen som er vesentlig med tanke på skolens oppdrag om å bygge elevenes friluftslivskompetanse, og å opprettholde og levendegjøre friluftsliv som en del av kulturarven.

Resultatene fra Wiken (2011) kan tolkes som at både elevenes kjennskap til hva som forventes relatert til friluftsliv, og hva de synes og tenker om friluftsliv i skolen kan være ganske forskjellig. Vår gjennomgang og analyse av de kvalitative studiene representerer kun små glimt fra noen enkelte elever, gjerne ved en enkelt skole eller med utgangspunkt i et bestemt friluftslivsopplegg. Der Haslestad (2000) og Repp (1993) viser hvordan friluftslivets mer ideologiske talsmenn har vært opptatt av skolen som bidragsyter for et tryggere friluftsliv og ansvar for natur og miljø som friluftslivspedagogisk utfordring, er dette bare perifert berørt i studiene med elevperspektiv. Ut over uteskole, som er et felles tema i fem av de kvalitative studiene, gir studiene små beretninger om friluftsliv i skolen som sosialiseringsarena, om betydning for motivasjon og læringsmiljø, noe om vurdering og om elevers opplevelser og læring i friluftsliv er i tråd med læreplanenes mål med friluftsliv. Selv om tre oppgaver har sett spesielt på opplevelser for elever med innvandrerbakgrunn, framtrer ikke perspektiver av hvordan mening og forståelse i friluftsliv konstrueres i skolen som sosial og kulturell kontekst. Spørsmål om hvordan elever er introdusert for, og fått hjelp til å verdsette, natur og friluftslivslivets egenverdi, tematiseres ikke. Det er, tørr vi si, overraskende lite om hva elevene kan og tenker om friluftsliv, om elevenes naturopplevelser, om deres refleksive prosesser og læring underveis. Det er, for å skjele til læreplanens generelle del, lite om hvordan elevene bruker «kropp og sansar til å oppdage nye stader og til å utforske omverda» (Utdanningsdirektoratet, 2015a). Det er mulig å se en svak utvikling i at elevenes opplevelser får komme mer direkte til uttrykk i studiene utover 2000-tallet, men det er vanskelig å si om dette skyldes en dreining $\mathrm{i}$ fokus eller om det har med at elevene $\mathrm{i}$ disse studiene er eldre og mer nærliggende å intervjue for å få del i deres refleksjoner og opplevelser. Med forbehold om at de fleste studiene bare representerer små glimt fra utvalgte elevers opplevelser med friluftsliv i skolen har vi allerede antydet hvilke tema som er løftet opp. Det er disse vi nå skal se nærmere på. 


\section{Hva vet vi om elevenes opplevelser og læring i friluftsliv?}

De forskjellige studiene og informantene benytter ulike ord og begreper, men de opplevelser og læringsutbytter som hyppigst løftes fram i studiene er relatert til sosial tilhørighet og gevinsten av samarbeid og samhandling (Foss, 2011; Garborg, 2003; Gøtz, 2014; Hvattum, 2012; Jakobsen, 2007; Rødby, 2006; Sølvik, 2003; Åvangen, 2008). Observasjonsstudier av uteskole viser en praksis hvor elevers medvirkning blir synlig, og hvordan elevene ser og anerkjenner hverandre i fri lek (Garborg, 2003; Jørgensen, 1999; Rødby, 2006). Selv om elevenes tanker og opplevelser bare unntaksvis kommer direkte til uttrykk i studiene fra trinn 1-7, beskrives det hvordan natur og romlighet inviterer til nye elevroller. God plass til utfoldelse synes å virke positivt på dynamikken elevene imellom, på konfliktnivå og mulighet for tilpasset opplæring. Sølvik (2003), som har studert adferdsvansker mer spesifikt, skriver at friluftsliv tilbyr sammenheng mellom oppgaver, løsninger og konsekvenser som oppleves meningsfull og forståelig for ungdommen. Atferdsproblematikken trer i bakgrunnen og elevene opplever sosial mestring. Særlig turer med lengre varighet gir anledning til å vise flere sider ved personligheten og utfordrer faste samhandlings- og adferdsmønster (Sølvik, 2003). Avbrekk fra det teoretiske skolearbeidet, det å se hverandre i nye roller og hvordan fellesskapsopplevelser utvikler og styrker samholdet, er sentrale kvaliteter når elever $\mathrm{i}$ videregående skole selv skal forklare turenes verdi (Hvattum, 2012; Åvangen, 2008).

Et annet moment vi ser i flere av studiene, er hvordan elever verdsetter undervisningsformer i friluftsliv hvor de blir delaktige og ansvarliggiort. Mikkelsen (2013) har gjennomført et undervisningsopplegg inspirert av selvbestemmelsesteorien til Deci og Ryan (2002). Elevene uttrykker at de har liten erfaring med medbestemmelse og valgfrihet i skolesammenheng. Åvangen (2008) løfter opp selvbestemmelse som en særlig kvalitet i elevenes erfaringer, noe de kan tenke seg ytterligere forsterket. I en kvalitativ studie av et femdagers tverrfaglig friluftslivsopplegg, løfter Kongsrud (2004) fram det positive forholdet mellom selvbestemmelse og engasjement som et hovedfunn. Det kan selvsagt diskuteres hvor mye motivasjonsteoriens begreper farger resultatene i de tre studiene, men vi merker oss gjennomgående a) at elever uttrykker lite erfaring med medbestemmelse og involverende arbeidsformer, og b) at de kan tenke seg mer av denne type undervisning. Medvirkning og valgmulighet virker å generere positive opplevelser av likeverdighet på tur og større motivasjon for både forberedelser og det som skjer underveis.

Ser en forbi opplevelsene av medvirkning og friluftslivets sosiale og rekreative kvaliteter, forteller elevstemmene lite om hva som læres i skolens friluftslivsundervisning. Sett under ett indikerer de 24 inkluderte studiene at læringsutbyttet når det gjelder friluftsliv i den erfarte lereplan er relativt tilfeldig. Relatert til grunnopplæringen drøfter både Abelsen (2002) og Jordet (2007) utfordringer med manglende bevissthet rundt elevenes læring i uteskole som praktisert arbeidsform. I andre enden av opplæringen, videregående skole, uttrykker elever at det er uklart hva de skal lære i friluftsliv (Bamle, 2009; Wiken, 2011). 


\section{K. Abelsen og P. E. Leirhaug}

Goodlad, Klein og Tye (1979) skrev at det er vanskelig å innhente gode data for den operasjonaliserte lareplan, men at samme prosjekt for den erfarte lareplan er «even more slippery» (s. 63). Det at elevene opplever å ikke lære noe i friluftsliv kan like gjerne være et uttrykk for hvordan elevene har en snever forstålse av begrepet læring. Studiene beskriver vesentlige læringsutbytter relatert til sosial læring og kompetanse, men det oppfattes ikke av elevene som læring. Når elevene hos Foss (2011) i programfag friluftsliv sier de i liten grad lærer noe nytt og stort sett repeterer kunnskap de allerede har, kan det også leses som oppfyllelse av læreplanens intensjoner om ansvarlighet og selvstendiggiøring (Gurholt, 2008; Leirhaug \& Arnesen, 2016). Hvis mange av ungdommene allerede har kompetanse til selv å utøve enkelt friluftsliv uten en aktiv nærværende lærer, gir det ny forståelse til at halvparten av elevene i Wiken (2011) oppga det som unødvendig å lære om friluftsliv.

Vi ser et behov for studier om hvordan lærere og elever kommuniserer rundt friluftsliv og forventet læring, men også teoretiske studier om hvordan progresjon skal forstås hvis den er ment å invitere til verdifulle naturopplevelser, til nysgjerrig oppdaging og utforsking av natur og seg selv i møtet med natur. Friluftsliv er også en arena for konkret refleksjon om klodens bærekraft og hvordan menneskets handlinger allid samspiller med naturen som kosmos. I lys av skolepolitiske intensjoner representerer utvikling av slike perspektiver, som altså er relativt fraværende i hva vi vet om elevenes opplevelser, en vesentlig utfordring, ikke bare for lærerkompetansen, men også til forskningen. Her er det et behov for å utarbeide friluftslivsdidaktisk teori og praksis, parallelt med en kontinuerlig drøfting av hva friluftsliv i skolen skal innebære. Hvis selvstendiggiøring og opplevelse av egenverdi i møte med natur og friluftsliv er sentrale mål skolefriluftslivet, er ekspertopplegg som krever ekstern spisskompetanse, særlig tilrettelagte anlegg eller avansert utstyr neppe veien å gå. Vi skal ikke forfølge disse refleksjonene, men vende tilbake til analysen. Vi vil ta for oss vurdering og friluftslivshabitus, to tema hvor elevenes beretninger og opplevelser synes å sprike i de studiene vi har sett på.

\section{Utfordringer med vurdering}

Vi har sett at det som skal læres i friluftsliv framstår uklart for elevene. Da er det ikke underlig at vurderingskriterier også oppfattes uklare og mangelfulle, og at usikkerhet forbundet med karaktergrunnlag kan føre til frustrasjon for elever (Naustdal, 2012). Likevel trenger ikke dette være tilfelle. Elevene i Hvattum (2012) opplever programfag friluftsliv som et avbrekk fra det teoretiske skolearbeidet og en ellers hektisk og vurderingsopptatt skolehverdag. Elevene i Bamles (2009) studie på idrettsfag uttrykte uklarhet omkring forventet læringsutbyttet i friluftsliv, men er eksplisitte på at de ønsker gode karakterer og opplever at innsats, samarbeid og gode holdninger vektlegges i vurderingen. I lys av læringsutbyttet som hyppigst beskrives, virker dette meningsfullt. To studier som inkluderer elever med innvandrerbakgrunn demonstrerer at så enkelt er det ikke.

Gøtz (2014) har undersøkt hvordan elever med ulik kulturell bakgrunn opplever undervisningen i friluftsliv på idrettsfag, og skriver at de «flerkulturelle elevene i denne 
oppgaven er enige om at hvis de hadde øvd mer på å stå på ski på forhånd, ville de fått bedre karakter» (s. 72). Manglende vinterlige forutsetninger viser seg avgiørende for vurdering og virker negativt på trivsel og motivasjon. Naustdal (2012) beskriver hvordan elever mister fokus på det sosiale og naturopplevelse på grunn av manglende kompetanse; perspektivet blir instrumentelt og opplevelsene preget av karakterjag. De tidligere beskrevne elevopplevelser av medbestemmelse og ansvar i friluftslivsundervisningen, ser ikke ut til å inkludere arbeid med kriterier og vurdering.

De fire studiene (Bamle, 2009; Hvattum, 2012; Naustdal, 2012 og Gøtz, 2014) som belyser elevers opplevelser med vurdering er alle fra etter innføringen av LK06. Denne voksende interessen for vurdering i studienes spørsmålsstillinger kan tolkes som uttrykk for at reformen medførte et generelt økt fokus på vurdering og vurderingens rolle i opplæringen. Ingen av studiene kommer med eksempler på hvordan vurdering kan brukes produktivt inn mot læringsmål. De illustrerer derimot at et økt fokus på vurdering kan komme til å overskygge andre verdier som elevene uttrykker sentrale i skolefriluftslivet.

\section{Utfordringer med manglende friluftslivshabitus}

Friluftsliv og innvandrere er et annet tema som $\mathrm{i}$ likhet med vurdering har fått økt fokus i senere tid. De tre studiene som inkluderer informanter med innvandrerbakgrunn og deres opplevelser, gir et tvetydig bilde av friluftsliv i skolen. Samtidig som de diskuterer hvordan fravær av primærsosialisering (Eriksen, 1997) og manglende forutsetninger eller habitus (Gøtz, 2014; Naustdal, 2012) bidrar til lav mestringsforventning og negative opplevelser, er det utsagn i disse studiene som tilsier at elevene opplever friluftsliv som en positiv avveksling, noe nytt og spennende - en aktivitetsform egnet for nye utfordringer og sosiale opplevelser. Informantene uttrykker seg positivt om prosesser som krever samarbeid, ansvarstaking og kommunikasjon - kompetanser som vi ikke bare finner igjen i opplæringens mål, men også vesentlig bidrag for å bli bedre kjent og utvikle vennskap.

Eriksen (1997) spør om friluftsliv er en egnet arena for integrering, noe som samfunnsmessig og politisk er interessant fordi forskning viser lavere deltakelse i friluftsliv blant innbyggere med minoritetsbakgrunn (NINA, 2014). Stortingsmeldinga om friluftsliv understreker at god informasion til denne gruppen er spesielt viktig (St. Meld. 18 (2015-2016), 2016, s. 81). En utfordring er at informantene hos Eriksen (1997) ikke virker å se overføringsverdien av opplevelser fra friluftslivsundervisning til dagliglivet. Denne studien er omtrent 20 år gammel og det flerkulturelle Norge har utviklet seg mye i mellomtiden. Selv om vårt materiale fram til 2014 ikke framviser en økt interesse for det flerkulturelle, kan vi forvente dette i kommende år. Det er allerede kommet flere studier etter vår undersøkelsesperiode. En av disse er Tune (2016), der to jenter med innvandrerbakgrunn eksemplifiserer andre historier enn Eriksen (1997). På spørsmål om hvorfor de har valgt programfag friluftsliv, viser jentene:

«...til ønsker om å kunne videreføre friluftslivsgleden til venner og familie med telt- og skiturer. De har begge størst erfaring med friluftsliv fra venner, barnehage 
eller skole. Programfag friluftsliv gir dem kompetansen de føler de trenger til å kunne gi en form for reversert sosialisering til friluftsliv med deres egen familie» (Tune, 2016, s. 70-71).

Med manglende primærsosialisering til friluftsliv, har jentene gjennom sekundærsosialiseringen tilegnet seg erfaringer med å være ute i naturen og lært å glede seg over dette. Begge har gått $\mathrm{i}$ en «skole der de vektlegger å legge deler av undervisningen ut $\mathrm{i}$ naturen» (s. 58), og Tune (2016) kommenterer at skolens effekt og rolle som sosialiseringsarena har vært sentral i elevenes dannelse og utdannelse til friluftsliv. Selv om dette er et enkelteksempel, skrevet fram i en masteroppgave, ser vi her at friluftsliv gjennom skolen kan fungere inkluderende for elever som ikke møter norsk natur og friluftsliv via familie og oppvekst ellers. Men bak denne type gode eksempler lurer mange uavklarte problemstillinger. Det kan gjelde innhold i friluftslivsundervisningen, hvordan friluftslivets egenverdi rekonstrueres i en skolesetting, timer til rådighet, skolens avstand til naturområder, muligheter for medbestemmelse og valg, lærernes kompetanse og samarbeid med lokale ressurspersoner og organisasjoner.

\section{Oppsummering og konklusjon}

I denne studien har vi gjennomgått og analysert empiriske studier 1974-2014 med elevperspektiv på friluftsliv i skolen. Materialet teller totalt 24 studier. Disse er i hovedsak kvalitative (21) og undersøkelsene fordeler seg på uteskole (7), kroppsøving i grunnskolen (7) og videregående skole (2), idrettsfag (4) og programfag friluftsliv (4). Når 18 av de 24 inkluderte studiene er utført på master- og hovedfagsnivå vil vi påpeke et bemerkelsesverdig fravær av bidrag fra etablerte forskere. Dette fører oss til å konkludere med at det knapt finnes empirisk forskningsbasert kunnskap om den erfarte lareplan av norsk skoles friluftslivsopplæring. Materialets omfang tillater ikke en tematisk syntetisering av resultatene (Thomas \& Harden, 2008). Vi kan derfor ikke trekke konklusjoner om hva som er typiske elevopplevelser fra friluftsliv i skolen, eller hva som preger effektiv friluftslivsundervising. Men innenfor rammen av de 24 inkluderte studiene uttrykker elever på tvers av skoleslag og alder at friluftsliv i skolen har kvaliteter som fremmer samhold, samarbeid og andre sider ved sosial kompetanse. Samtidig illustrerer analysen at friluftsliv og dets mulige kvaliteter konstitueres gjennom didaktiske praksiser der elever og lærere samhandler. Friluftsliv i skolen er ikke et ferdig forstått fenomen. Friluftslivet kan ikke leses rett ut av læreplanene, det må fylles med mening og verdi. Vår gjennomgang av studier med elevperspektiv, selv om de er få, viser nettopp dette. Det er studier der elevene i hovedsak beskriver friluftsliv som avbrekk fra en ellers teoripreget skolehverdag, samtidig som vi også finner studier der elever opplever karakterjag i friluftsliv. I materialet er det to studier hvor elever med innvandrerbakgrunn opplever at det forventes bakgrunnskunnskap og ferdigheter som de ikke har grunnlag for å mestre, mens friluftslivsundervisningen $\mathrm{i}$ andre studier framtrer positivt og motiverende ved at elevene opplever reelt ansvar og medvirkning. 
For å oppsummere er det fristende å si at friluftsliv i elevperspektivets prisme framtrer som et mangfoldig fenomen. Med 24 inkluderte studier, hvor tema og elevgruppe varierer, er det ikke mulig å avgjøre om det er studienes perspektiver som styrer hva vi får vite noe om, mer enn hva elevene faktisk lærer og opplever i skolefrilutslivet. I forlengelsen av dette er det vi spør hva vi ikke vet om elevenes opplevelser og læringsutbytte. Det kan like gjerne være måten studiene er gjennomført på, spørsmålsstillingene og teoriene det bygges på, som fører til at enkelte perspektiver løftes frem og andre tilskygges. Vi kan derfor gjenta Leirhaug og Arnesens (2016) påpekning av et akutt behov for å utforske og dokumentere hva elever får ut av eksisterende friluftslivsundervisning. Vi vil også understreke skolen og lærernes ansvar overfor det intensjonelle og formelle læreplannivået og på behov for større og mer langsiktige utviklingsprosjekter, og da spesielt med et fokus rundt didaktisk praksis, naturopplevelser, elevenes læring og kroppsliggjøring av kunnskap i friluftsliv. Det hevdes stadig, senest i nevnte Stortingsmelding (Meld. St. 18 (2015-2016), 2016), at friluftsliv kan inkluderes i mange av skolens fag, at nærmiljøet representerer en viktig kunnskapskilde og læringsarena. Meldingen relaterer til spennende prosjekter og undervisningspraksis hvor friluftsliv synes å få særlig oppmerksomhet. I fortsettelsen blir det viktig at slike eksempler blir gjenstand for forskningsmessig tilnærming.

\section{Biography}

Kristian Abelsen er ansatt ved Norges Idrettshøgskole, Seksjonen for Kroppsøving og Pedagogikk. Forskning og undervisning er relatert til faglærerutdanningen og studieprogrammene i friluftsliv ved seksjonen. Han har bakgrunn som uteskolelærer i ungdomsskolen og lærer i folkehøgskolen. Forskningsinteressen sentrerer omkring didaktikk for friluftsliv i skolen.

Petter Erik Leirhaug er førsteamanuensis ved Høgskulen på Vestlandet. Forskning og undervisning er knyttet til lærerutdanningen og bachelor- og masterstudiene innen friluftsliv, idrett og kroppsøving. Han har bakgrunn som lærer i grunnskolen og i videregående skole, og har skrevet doktorgrad om vurdering for læring i kroppsøving ved Norges idrettshøgskole.

\section{Litteraturliste}

Aamelfot, A.M. (1994). Valgfag friluftsliv $i$ ungdomsskolen: en kartlegging av utbredelse og omfang av valgfag friluftsliv på ungdomstrinnet $i$ Norge $i$ 1989. Hovedfagsoppgave. Oslo: Norges idrettshøgskole.

Abelsen, K. (2002). Uteskole og lererprofesjonalitet. Visjoner og virkelighet. Hovedfagsoppgave. Oslo: Norges idrettshøgskole.

Annerstedt, C. (2008). Physical Education in Scandinavia with focus on Sweden - a comparative perspective. Physical Education and Sport Pedagogy, 13(4), 303-318.

Augestad, P. (2003). Skolering av kroppen. Om kunnskap og makt i kroppsøvingsfaget. Doktoravhandling. Bø: Høgskolen i Telemark.

Åvangen, L.S. (2008). Friluftsliv på idrettsfag $i$ en videregående skole: en kvalitativ studie av fire elevers opplevelser, erfaringer og laringsutbytte $i$ friluftslivsundervisningen på idrettsfag $i$ en videregående skole. Masteroppgave. Oslo: Norges idrettshøgskole.

Backman, E. (2011). «Friluftsliv»: A Contribution to Equity and Democracy in Swedish Physical Education? An Analysis of Codes in Swedish Physical Education Curricula. Fournal of Curriculum Studies, 43(2), $269-288$.

Bamle, A.B. (2009). Fra lereplan til lering: en kvalitativ undersøkelse av sammenhengen mellom lcereplanens intensjoner og undervisningsaktivitetens realiteter. Masteroppgave. Oslo: Norges idrettshøgskole.

Baumeister, R.F. (2013). Writing a literature review. I Prinstein, M.J. \& Patterson, M.D. (red.), The portable mentor: Expert guide to a successful career in psychology (s. 119-132). New York: Springer Science + Business Media. 


\section{K. Abelsen og P. E. Leirhaug}

Borgen, J.S. \& Engelsrud, G. (2015). Hva skjer i kroppsøvingsfaget? Bedre skole, nr. 2, $62-67$.

Dalebø, G. (1996). «Den opplevde barriereplan» Ei undersøking omkring implementering av friluftsliv $i$ kroppsøving ved fire videregående skular. Hovedfagsoppgave. Oslo: Norges idrettshøgskole.

Deci, E.L. \& Ryan, R.M. (red.) (2002). Handbook of self-determination research. Rochester, NY: University of Rochester Press.

Eriksen, J.W. (1997). Friluftsliv som arena for integrering av ungdom med innvandrerbakgrunn. En kvalitativ undersøkelse om ungdom med innvandrerbakgrunn sitt forhold til friluftsliv, sett $i$ et integreringsperspektiv. Hovedfagsoppgave. Oslo: Norges Idrettshøgskole.

Fjørtoft, I. \& Larsen, R. (2005). Høy puls i uteskolen! En pilotstudie av elever i 1.-4. klasse i Uteaktiviteter. I Rapport fra konferanse $i$ forskning $i$ friluft. Oslo: FRIFO.

Foss, J.C. (2011). «Uforpliktende gøy eller faglig moro?» Om elevers selvopplevde laring $i$ friluftsliv valgfag. Masteroppgave. Oslo: Norges idrettshøgskole.

Garborg, L. (2003). Uteskole og klassemiljø: en studie av erfaringer med uteskole $i$ 7. klasse på Lutvann skole. Hovedfagsoppgave. Oslo: Norges idrettshøgskole.

Goodlad, J.I., Klein, M.F. \& Tye, K.A. (1979). The domains of curriculum and their study. I J.I. Goodlad and Associates. Curriculum inquiry. The study of curriculum practice (s. 43-76). New York: McGraw-Hill.

Gurholt, K.P. (2005). Kunnskapsløft i friluftsliv: innspill til høring - LP06. Kroppsøving, 55(3), 6-9.

Gurholt, K.P. (2008). Norwegian Friluftsliv as Bildung - a Critical Review. I Becker, P. \& Schirp, J. (red.), Other Ways of Learning (s. 131-155). Marburg: European Institute for Outdoor Adventure Education and Experiential Learning (EOE).

Grønningseter, I., Hallås, O. \& Kristiansen, T. (2005). Uteskole og fysisk aktivitet i en 6 . klasse. Sammenligning av aktivitetsnivå på en uteskoledag og en tradisjonell skoledag. I Rapport fra konferanse $i$ forskning $i$ friluft. Oslo: FRIFO.

Gøtz, J.H. (2014). Friluftsliv og kulturell bakgrunn: en kvalitativ studie av hvordan elever med en fremmedkulturell bakgrunn opplever friluftslivsundervisning $i$ forhold til etnisk norske elever. Masteroppgave. Oslo: Norges idrettshøgskole.

Haslestad, K.A. (2000). På leting etter hva friluftsliv egentlig er - med utgangspunkt $i$ ulike perspektiver - og med et spesielt fokus på friluftsliv $i$ grunnskolens lareplaner de siste nesten seksti årene. Hovedfagsoppgave. Oslo: Universitetet i Oslo.

Haugsjå, S. (1975). Noen refleksjoner omkring friluftsliv $i$ skolen. Stensiltrykk 23/75. Oslo: Norges idrettshøgskole.

Hvattum, T.T. (2012). Friluftsliv som valgfag $i$ den videregående skole: $i$ spennet mellom selvrealisering og formålsrasjonelle handlinger. Masteroppgave. Bø i Telemark: Høgskolen i Telemark.

Jacobsen, E.B., Moser, T., By, I.-Å., Fjeld, J., Gundersen, K.T. \& Stokke, R. (2006). L97 og kroppsøvingsfaget fra blå praktbok til grå hverdag? Synteserapport. NFR. Hentet 2. august 2016 fra http://www.forskningsradet. no/servlet/Satellite?c=Page\&pagename $=$ ForskningsradetNorsk $\% 2$ FHovedsidemal\&cid $=1175003277667 \&$ querystring $=$ jacobsen + kropps $\% \mathrm{C} 3 \% \mathrm{~B} 8$ ving\&spell $=$ true \&filters $=$ cssitename $\% 2 \mathrm{C} \% 21$ Forskningsradet Engelsk \%2C\%2Clangcodes \%2Cno\&isglobalsearch=true\&configuration=nfrsearchersppublished

Jacobsen, E.B., Moser, T., By, I.-Å., Fjeld, J., Gundersen, K.T. \& Stokke, R. (2002). L97 og kroppsøvingsfaget fra blå praktbok til grå hverdag? Elevenes og lerernes erfaringer knyttet til den nye lareplanen $i$ kroppsøving. Hovedrapport 2. Rapport 5/2002. Tønsberg: Høgskolen i Vestfold.

Jakobsen, J.E. (2007). Friluftsliv $i$ ungdomsskolen: skolen kan hvis skolen vil. Hovedfagsoppgave. Oslo: Norges idrettshøgskole.

Jordet, A.N. (2007). Narmiljø som klasserom: en undersøkelse om uteskolens didaktikk $i$ et danningsteoretisk og erfaringspedagogisk perspektiv. Doktoravhandling. Oslo: Universitetet i Oslo.

Jordet, A.N. (2010). Klasserommet utenfor. Oslo: Cappelen Damm.

Jørgensen, P.B. (1999). «At stikke hovedet ind i naturen.» En empirisk studie af udeskole som pedagogisk arbejdsform. Hovedfagsoppgave. Bø: Høgskolen i Telemark.

Kongsrud, T.D. (2004). Friluftsliv $i$ ungdomsskolen $i$ et elevperspektiv: hvordan opplever elevene undervisningen der det utvidede klasserommet er et primitivt skogsmiljø. Hovedfagsoppgave. Oslo: Norges idrettshøgskole.

KUF (1974). Mønsterplanen 1974. Oslo: Aschehoug.

KUF (1987). Mønsterplanen 1987. Oslo: Kirke-, utdannings- og forskningsdepartementet.

Kårhus, S. (1975). Friluftsliv som økopedagogikk, verdigrunnlag og retningslinjer for friluftsliv som modell $i$ miljølcereundervisning i gymnaset. Hovedfagsoppgave. Oslo: Pedagogisk forskningsinstitutt.

Leirhaug, P.E. \& Arnesen, T.E. (2016). Friluftsliv - et hovedområdet i kroppsøvingsfaget? I Horgen, A., Fasting, M.L., Lundhaug, T., Magnussen, L.I. \& Østrem, K. (red.), Ute! Friluftsliv - pedagogiske, historiske og sosiologiske perspektiver (s. 129-152). Bergen: Fagbokforlaget. 


\section{Hva vet vi (ikke) om elevers opplevelser med friluftsliv $i$ norsk skole}

Leirhaug, P.E. \& Klepsvik, K. (2010). Har skulen snudd ryggen til naturen? Nokre resultat frå og refleksjonar $i$ etterkant av ei undersøking om uteskule og friluftsliv $i$ skulen blant grunnskulelcerarar $i$ Hordaland og Sogn og Fjordane (s. 175-182). Rapport fra Forskning i friluft 2009. Oslo: Friluftslivets fellesorganisasjon.

Lund, T. (2014). Lererens tilrettelegging for elevens lering $i$ skolens friluftsliv. Masteroppgave. Sogndal: Høgskolen i Sogn og Fjordane.

Meld. St. 18 (2015-2016). (2016). Friluftsliv - Natur som kilde til helse og livskvalitet. Hentet fra https://www. regjeringen.no/no/dokumenter/meld.-st.-18-20152016/id2479100/

Mikkelsen T. (2013). Friluftslivsundervisning i videregående skole: Autonomi eller kontroll? Masteroppgave. Oslo: Norges idrettshøgskole.

Mytting, I. (1991). Trenger vi friluftsliv i skolen. I Repp, G. (red.). Opplaring og tryggleik $i$ friluftsliv. (Seminarrapport, s. 51-65). Volda: Volda lærarhøgskule.

Naustdal, E.K. (2012). «Hvorfor skal jeg reise så langt bare for å få tre?»: Kvalitativ analyse av minoritetsungdoms livserfaringer $i$ møte med friluftsliv på idrettsfag. Masteroppgave. Oslo: Norges idrettshøgskole.

NINA. (2014). Friluftsliv $i$ Norge anno 2014 - status og utfordringer (1073). Lillehammer: Norsk institutt for naturforskning.

Nygård, B.-A. (2012). «To fluer $i$ en smekk» En kvalitativ studie av friluftsliv på universitetsnivå $i$ den videregående skolen. Masteroppgave. Oslo: Norges idrettshøgskole.

Repp, G. (1993). Natur og friluftsliv i grunnskulen. Rapport. Volda: Møreforskning.

Rødby, H.E. (2006). En studie om tilpasset opplaring $i$ uteskolen. Masteroppgave. Oslo: Norges idrettshøgskole.

Skogvang, B.O. (1993). Sosialisering til friluftsliv: en kartleggingsundersøkelse av friluftsliv blant personer som var gymnaselever $i$ Trondheim på 1970-tallet: påvirkning under oppvekst og gymnastid og friluftslivsvaner $i$ dag. Hovedfagsoppgave. Oslo: Norges idrettshøgskole.

St.meld. 30 (2003-2004). (2004). Kultur for laring. Hentet fra https://www.regjeringen.no/no/dokumenter/ stmeld-nr-030-2003-2004-/id404433/

Sølvik, R.M. (2003). Friluftsliv: ein aktuell sosial leringsarena for ungdom med åtferdsvanskar? Hovedoppgåva i Spesialpedagogikk. Oslo: Universitetet i Oslo.

Thomas, J. \& Harden, A. (2008). Methods for the thematic synthesis of qualitative research in systematic reviews. BMC Medical Research Methodology 8(45), s. 1-10. doi:10.1186/1471-2288-8-45.

Timmins, F. \& McCabe, C. (2005) How to conduct an effective literature review. Nurs Stand 20(11), 41-47.

Tune, O.-J. (2016). «Å jobbe med menneskesjela»: Hvilken forståelse har lcerere og elever $i$ videregående opplaring av friluftsliv som fenomen, og hvordan erfares friluftslivsundervisningen med bakgrunn $i$ denne forstålsen og deres livserfaring? Masteroppgave. Oslo: Høgskolen i Oslo og Akershus.

Utdanningsdirektoratet. (2015a). Lereplanverket for kunnskapsløftet. Generell del. Hentet 20. august 2016 fra https:/www.udir.no/laring-og-trivsel/lareplanverket/generell-del-av-lareplanen/

Utdanningsdirektoratet. (2015b). Lereplan i kroppsøving. Hentet 20. august 2016 fra http://www.udir.no/k106/ KRO1-04

Utdanningsdirektoratet. (2006). Lereplan i aktivitetslare. Hentet 22. februar 2017 fra https://www.udir.no/k106/ IDR1-01

Valdal, S.A. (2013). Friluftsliv $i$ vest og øst: En kvalitativ studie om elevers og lereres oppfatninger av programfag friluftsliv på en videregående skole. Masteroppgave. Oslo: Norges idrettshøgskole.

Wiken, A.R. (2011). Hva lcerer vi i kroppsøving? Hva oppfatter elevene selv at de larer, og er dette $i$ tråd med Kunnskapsløftet 2006? Masteroppgave. Oslo: Norges idrettshøgskole. 